1. AMERICAN ORNITHOLOGISTS' UNION. 1983. Check-list of North American birds, 6th Edition. Allen Press. Lawrence, Kansas. 877 pp.

2. CAMPBELL, R.W., N.K. DAWE, I. MCTAGGART-COWAN, J.M. COOPER, G.W. KAISER and M.C.E. MCNALL. 1990. The birds of British Columbia. Volume II: Nonpasserines, diurnal birds of prey through woodpeckers. Royal British Columbia Museum. Victoria. $636 \mathrm{pp}$.

3. GODFREY, W.E. 1986. The birds of Canada. Revised edition. National
Museum of Canada. 595 pp.

4. SADLER, T.S. and M.T. MYRES. 1976. Alberta birds 1961-1970. Occ. Paper No. 1. Natural History Section, Provincial Museum of Alberta, Edmonton. $314 \mathrm{pp}$.

5. SEEL, K.E. 1969. An annotated list of the avifauna of Waterton Lakes National Park. Nat. and Hist. Parks Branch, Dept. of Indian Affairs and Northern Development. Park files, Waterton. $281 \mathrm{pp}$.

\title{
THE URBAN ROCK WREN
}

ROBERT WAPPLE, \#3 - 513 Dufferin Avenue, Saskatoon, Saskatchewan. S7N 1 C2

I usually do a lot of bird-watching in Saskatoon during the last two weeks of August each year, as this is when the fall warbler migration peaks. It was one of these warblerwatching days, 20 August 1991, which provided me with an unusual "birding" experience.

It was high noon and blazing hot when I returned home after a short but exhausting walk through Cosmopolitan Park, along the east bank of the South Saskatchewan River. Although the park is just a short distance from where I live, the heat made the outing simply unbearable. However, after finding many species of migratory songbirds, I felt well rewarded for my effort.

After eagerly gulping down a litre of iced tea, I decided to step outside onto my balcony, which overlooks the backyard from an elevation of approximately $4 \mathrm{~m}$. Its strategic loca- tion offers an excellent vantage point for spotting sneaky birds moving through the yard. The sun was blazing off the east-facing deck, making the surface temperature resemble that of hot coals! There did not seem to be much bird activity in the yard which was unusual for that time of year. However, I soon noticed some movement to my left and there, hanging upside down from the stucco wall of my neighbour's house, was a rather content looking Rock Wren.

The bird soon flew onto the roof of the house and hopped into the eaves trough where I could hear it clawing and scratching as it explored the length of it. Upon reaching the end, it climbed over the edge of the trough and landed on the side of the house again. The bird repeated this action several times as I stood less than 4 $\mathrm{m}$ away, quite amused, needless to say. 
However, my amusement ended abruptly as I though to myself, "Now who is going to believe this?" I phoned my brother Guy, who, after I did some convincing, said he would come over. However, he decided to run a few errands on the way, and did not arrive until a full hour later, shaking his head at my enthusiastic description of what had happened. Of course, I had not seen the wren since our phone call, but by now there were numerous birds moving through the yard so I convinced him to stay and check things out.

Patiently, we sat out in the heat swilling Kool-Aid like a couple of seven-year-olds until, remarkably, the Rock Wren suddenly reappeared
90 minutes after the original sighting! It was exploring the dead branch of a large elm that hangs over the balcony. We were directly beneath the bird and watched as it worked its way down the branch, upside down in a nuthatch-like fashion. When it reached the main trunk of the tree, the wren flew away, this time for good.

Since there is an obvious lack of Rock Wren habitat in Saskatoon, I suppose the stucco-coated house was the closest thing to a rocky outcropping the bird could find. My suggestion is, if you live in or near one of these houses, keep your eyes open for the elusive urban Rock Wren.

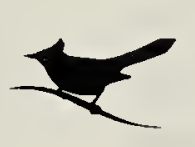

\section{MOUNTAIN BLUEBIRD NESTS IN CLOTHES DRYER VENT}

W.H. KOONZ, Manitoba Department of Natural Resources, 1495 St. James Street, Winnipeg, Manitoba. R3H OW9

On 14 and 15 June 1993, I stayed at a government bunkhouse in Aessippi Provincial Park, northwest of Riding Mountain National Park. I found Mountain Bluebirds nesting in a clothes dryer vent and in a bird house on a power pole some $30 \mathrm{~m}$ in front of the building.

The dryer vent was an aluminum tube $9 \mathrm{~cm}$ in diameter and $60 \mathrm{~cm}$ long, attached to a semitransparent plastic tube which led to the dryer. The plastic flap covering the outside end of the vent had fallen off leaving an entrance hole $30 \mathrm{~cm}$ above ground. Nesting material filled the plastic tube toward the dryer end 15 $\mathrm{cm}$ from where it intersected with the aluminum pipe. Three nestlings nested on shallow material up against the nest bulk.

No one had stayed at the bunkhouse until 7 June and the dryer had not been used in 1993. Despite an area cleanup on 15 June (shrubs trimmed and grass cut), the adult birds continued to attend their young. 